\title{
ANALISIS FAKTOR MOTIVASI KERJA TKA \\ (TENAGA KERJA ASING) PADA HOTEL BERBINTANG DI \\ KECAMATAN KUTA SELATAN KABUPATEN BADUNG BALI
}

\author{
Putu Yunita Wacana Sari \\ Prodi Magister Pariwisata Universitas Udayana \\ Email: yunita.wacanasari@gmail.com \\ Agung Suryawan Wiranatha \\ Pusat Unggulan Pariwisata Universitas Udayana \\ Email: balitruly@yahoo.com \\ I Putu Gde Sukaatmadja \\ Prodi Magister Pariwisata Universitas Udayana \\ Email: sukaatmadja@yahoo.co.id
}

\begin{abstract}
The tourism sector in the southern part of Bali, especially in South Kuta District, Badung Regency, Bali has been significantly developed with the development of the star-rated hotels. The development of this star-rated hotels certainly opened working opportunities for the foreign labour. In accordance with the increasing number of those foreign labour therefore, this study was conducted with the aim of analysing the factors that motivate foreign labour to work at star-rated hotels in the South Kuta District, Badung Regency, Bali. The data collection techniques used were limited interviews, documentation and literature study. The population are all expatriates who work at star-rated hotels in South Kuta District, Badung Regency, Bali based on IMTA data from the Badung Regency Industry and Manpower Office for the 20172018 period, with a sample size of 100 respondents selected by quota sampling. The instrument in the form of a questionnaire was used to obtain respondent data. The data analysis technique used in this research is factor analysis. The result of this study showed that the twenty variables of this study were classified into 4 (four) factors, namely: Compensational Factor (Payment and Status), Interpersonal Relationship Factor (Interpersonal Relations), Work Factor (Work Itself), and Development Factor (Personal Development). These four factors were the motivation factors for foreign labour to work at star- rated hotel in South Kuta District, Badung Regency, Bali.
\end{abstract}

Keywords: Foreign Labour, Working Motivation, Factor Analysis 


\section{Pendahuluan}

Pulau Bali merupakan satu dari sekian banyak daerah tujuan wisata dunia yang telah lama dikenal dengan keindahan alamnya yang mempesona, budayanya yang unik serta keramahtamahan masyarakatnya yang santun. Dari tahun ke tahun, angka kunjungan wisatawan baik lokal maupun mancanegara terus mengalami peningkatan yang signifikan

(BPS Kabupaten Badung, 2016). Dapat dikatakan bahwa Bali sebagai gerbang utama masuknya wisatawan mancanegara memegang peranan penting khususnya dalam perkembangan industri pariwisata di Indonesia. Potensi pariwisata yang luar biasa inilah yang kemudian menarik kaum kapitalis nasional maupun internasional untuk menginvestasikan modalnya di Bali. Salah satu bisnis yang dirasa cukup menjanjikan bagi para investor adalah bisnis perhotelan. Hal ini ditunjukkan dengan semakin meningkatnya jumlah hotel yang dibangun di Bali.

Fenomena globalisasi yang terjadi saat ini menjadikan Bali sebagai surga bagi perusahaan- perusahaan multinasional untuk membangun dan mengembangkan bisnisnya. Dalam menjalankan operasional bisnisnya, perusahaan-perusahaan multinasional tersebut akan memperkerjakan ekspatriat terutama untuk jabatanjabatan strategis manajerial dan board of directors. Hal ini sangat wajar dilakukan oleh perusahaan dari negara asal untuk memastikan bahwa dalam proses bisnis mereka para ekspatriat ini bisa membantu karyawan lokal untuk menyesuaikan diri sesuai nilai-nilai dan tujuan perusahaan. Terlebih lagi jika bisnis yang mereka lakukan ini harus melibatkan teknologi tingkat tinggi.

Keberadaan hotel berbintang tersebar diseluruh Indonesia dan berdasarkan data statistik diketahui hotel berbintang terbanyak di Indonesia berada di Provinsi Bali, yakni sebanyak 507 hotel (BPS Provinsi Bali, 2019). Berdasarkan data yang tercatat, dari 507 hotel berbintang yang ada di Provinsi Bali, sebanyak 394 hotel berada 
di Kabupaten Badung (BPS Provinsi Bali, 2019). Pada tahun 2017 Provinsi Bali pernah tercatat menempati urutan pertama tingkat hunian tertinggi, dengan persentase mencapai 74,86 persen pada hotel berberbintang di bulan Agustus (BPS, 2017). Hal tersebut tentu saja memberikan keuntungan tersendiri bagi para pengusaha hotel berbintang dan menjadi nilai tambah bagi tenaga kerja dari Bali maupun luar Bali untuk bekerja pada hotel berbintang di Bali, sehingga hal ini semakin menguatkan indikasi adanya daya tarik penduduk pendatang untuk bekerja di Bali. Sehubungan dengan adanya indikasi daya tarik penduduk pendatang untuk bekerja pada hotel berbintang, salah satu data yang dapat menjadi gambaran lebih lanjut adalah meningkatnya jumlah penduduk migran atau pendatang yang bekerja di Bali. Ekspatriat yang bekerja di Badung pada khususnya, terus mengalami peningkatan.

Hukum ketenagakerjaan di Indonesia mendukung keberadaan ekspatriat sebagaimana tercermin dalam UU No. 25 tahun 2007 tentang Penanaman Modal. Menurut Undang Undang (UU) No. 13 tahun 2003 tentang Ketenagakerjaan, yang dimaksud dengan tenaga kerja asing (TKA) adalah warga negara asing pemegang visa dengan maksud bekerja di Indonesia. Sesuai dengan pasal 31 PP No. 32 Tahun 1994 tentang Visa, Izin Masuk, dan Izin Keimigrasian (PP No.32/1994), ekspatriat di Indonesia menggunakan Kitas (Kartu Izin Tinggal Terbatas) sebagai dokumen legal yang melindungi keberadaan dan pekerjaan mereka selama di Indonesia.

Di era globalisasi seperti sekarang ini sangat mudah bagi seseorang untuk pindah dari satu negara ke negara lain yang sudah tentu memiliki latar budaya yang berbeda. Badan Pusat Statistik Provinsi Bali mencatat ekspatriat yang masuk dan bekerja di Provinsi Bali terus mengalami peningkatan dari tahun ke tahun dan tercatat pada tahun 2018, ekspatriat yang bekerja di Provinsi Bali khususnya yang bekerja pada hotel berbintang jumlahnya mencapai 272 orang (BPS, 2018). Dibandingkan dengan jumlah ekspatriat yang bekerja di Provinsi lainnya di Indonesia, jumlah tersebut merupakan jumlah tertinggi yang tercatat pada data BPS tahun 2018, hal ini 
menunjukkan tingginya minat ekspatriat untuk bekerja pada hotel berbintang yang ada di Provinsi Bali.

Berdasarkan latar belakang tersebut, penelitian lebih lanjut terkait faktor-faktor yang memotivasi ekspatriat untuk bekerja, khusunya pada hotel berbintang di Kecamatan Kuta Selatan, Kabupaten Badung perlu untuk dilakukan sehingga faktorfaktor yang paling memotivasi mereka untuk bekerja dapat diidentifikasi, mengingat jumlah ekspatriat yang bekerja dan menduduki posisi manajerial pada hotel berbintang khususnya di Kecamatan Kuta Selatan, Kabupaten Badung, Bali terus mengalami peningkatan.

\section{Landasan Teori dan Konsep}

Konsep dalam penelitian ini akan difokuskan pada faktor-faktor yang memotivasi tenaga kerja asing (ekspatriat) untuk bekerja pada hotel berbintang khususnya di Kecamatan Kuta Selatan, Kabupaten Badung, Bali. Adapun variabel/indikator yang digunakan dalam penelitian ini berasal dari teori Hygiene Motivation yang dikemukakan oleh Siagian (2006). Faktor-faktor tersebut antara lain faktor motivator yakni berhubungan dengan aspek-aspek yang terkandung dalam pekerjaan itu sendiri yang disebut juga sebagai aspek intrinsik dalam pekerjaan. Faktor- faktor yang termasuk dalam faktor motivator atau intrinsik adalah Prestasi (Achivement), Pengakuan (Recognition), Tanggung Jawab (Responsibility), Kemajuan (Advancement), Pekerjaan itu sendiri (Work Itself), Perkembangan (Personal Growth).

Selanjutnya, faktor yang kedua adalah faktor hygiene yang berhubungan dengan aspek disekitar pelaksanaan pekerjaan yang disebut juga aspek ekstrinsik pekerja, yang terdiri dari Kompensasi (Payment and Status), Keamanan dan Keselamatan Kerja (Job Security), Kondisi Kerja (Working Conditions), Kebijakan (Company Policy and Administration), Supervisi Teknis (Technical Supervision), 
Hubungan Interpersonal Antar Teman Sejawat, Dengan Atasan dan Dengan Bawahan (Intrerpersonal Relation).

\section{Metode Penelitian}

Penelitian ini dilakukan dengan menggunakan metode wawancara terbatas dan penyebaran kuesioner untuk mengumpulkan data mengenai faktor-faktor yang memotivasi ekspatriat untuk bekerja pada hotel berbintang di Kecamatan Kuta Selatan, Kabupaten Badung, Bali Metode analisis data yang digunakan dalam penelitian ini adalah teknik analisis kuantitatif. Analisis kuantitatif yang dipergunakan dalam penelitian ini adalah analisis faktor. Analisis faktor merupakan suatu teknik untuk menganalisis tentang saling ketergantungan dari beberapa variabel dengan tujuan untuk menyederhanakan dari bentuk hubungan antara beberapa variabel yang diteliti menjadi sejumlah faktor yang lebih sedikit dari pada variabel yang diteliti (Suliyanto, 2005).

Dalam penelitian ini yang menjadi populasi adalah seluruh ekspatriat yang bekerja pada hotel berbintang di Kecamatan Kuta Selatan, Kabupaten Badung Bali berdasarkan dari data IMTA Dinas Peridustrian dan Tenaga Kerja Kabupaten Badung periode 2017-2018 yakni sebanyak 146 orang.

Melalui analisis faktor, maka dapat diketahui faktor-faktor yang memotivasi ekspatriat untuk bekerja pada hotel berbintang di Kecamatan Kuta Selatan Kabupaten Badung Bali yang diidentifikasi dari 20 variabel penentu. Sampel responden yang berjumlah 100 orang merupakan sampel yang dipilih secara quota sampling dari populasi, sebanyak masing-masing 5 orang ekspatriat yang bekerja di 20 hotel diambil sebagai responden. Analisis data dalam penelitian ini menggunakan analisis faktor dengan bantuan program IBM SPSS statistics Version 25 for Windows. 


\section{Hasil Penelitian}

Analisis Pengujian Instrumen Faktor-Faktor Yang Memotivasi Ekspariat Untuk Bekerja Pada Hotel Berbintang Di Kecamatan Kuta Selatan Kabupaten Badung Bali Uji Validitas

Pada uji validitas ini sebanyak 20 pernyataan digunakan untuk mengetahui faktor-faktor yang memotivasi ekspatriat untuk bekerja pada hotel berbintang di Kecamatan Kuta Selatan Kabupaten Badung Bali dengan mengambil 30 sampel awal untuk dilakukan pengujian, maka didapatkan hasil rtabel sebesar 0,300. Pengujian validitas instrumen dalam penelitian ini menggunakan program IBM SPSS statistics version 25 for Windows. Hasil uji validitas instrumen penelitian terhadap variabelvariabel yang mempengaruhi faktor-faktor yang memotivasi ekspatriat untuk bekerja pada hotel berbintang di Kecamatan Kuta Selatan Kabupaten Badung Bali tersaji pada Tabel 1 sebagai berikut: 
Tabel 1. Hasil Uji Validitas

\begin{tabular}{|c|c|c|c|c|c|}
\hline $\begin{array}{c}\text { Variabel } \\
\text { Penelitian }\end{array}$ & Indikator & Pertanyaan & rhitung & $r$ table & Keterangan \\
\hline \multirow{7}{*}{$\begin{array}{l}\text { Motivasi } \\
\text { Intrinsik }\end{array}$} & Prestasi (Achivement) & I.1 & 0.666 & 0.300 & Valid \\
\hline & $\begin{array}{l}\text { Pengakuan } \\
\text { (Recognition) }\end{array}$ & $\mathrm{I} .2$ & 0.612 & 0.300 & Valid \\
\hline & $\begin{array}{ll}\text { Tanggung } & \text { Jawab } \\
\text { (Responsibility) } & \\
\end{array}$ & $\mathrm{I} .3$ & 0.696 & 0.300 & Valid \\
\hline & $\begin{array}{l}\text { Kemajuan } \\
\text { (Advancement) }\end{array}$ & $\mathrm{I} .4$ & 0.654 & 0.300 & Valid \\
\hline & $\begin{array}{l}\text { Pekerjaan itu sendiri } \\
\text { (Work Itself) }\end{array}$ & I.5 & 0.668 & 0.300 & Valid \\
\hline & Perkembangan & I.6 & 0.772 & 0.300 & Valid \\
\hline & (Personal Development) & I.7 & 0.811 & 0.300 & Valid \\
\hline \multirow{13}{*}{$\begin{array}{l}\text { Motivasi } \\
\text { Ekstrinsik }\end{array}$} & \multirow{3}{*}{$\begin{array}{l}\text { Kompensasi (Payment } \\
\text { and Status) }\end{array}$} & E. 8 & 0.448 & 0.300 & Valid \\
\hline & & E.9 & 0.789 & 0.300 & Valid \\
\hline & & E.10 & 0.746 & 0.300 & Valid \\
\hline & \multirow{2}{*}{$\begin{array}{ll}\text { Keamanan dan } \\
\text { Keselamatan Kerja (Job } \\
\text { Security) }\end{array}$} & E.11 & 0.766 & 0.300 & Valid \\
\hline & & E.12 & 0.435 & 0.300 & Valid \\
\hline & \multirow{2}{*}{$\begin{array}{l}\text { Kondisi Kerja (Working } \\
\text { Conditions) }\end{array}$} & E.13 & 0.612 & 0.300 & Valid \\
\hline & & E.14 & 0.537 & 0.300 & Valid \\
\hline & \multirow{2}{*}{$\begin{array}{l}\text { Kebijakan (Company } \\
\text { Policy and } \\
\text { Administration) }\end{array}$} & E.15 & 0.738 & 0.300 & Valid \\
\hline & & E.16 & 0.737 & 0.300 & Valid \\
\hline & $\begin{array}{l}\text { Supervisi Teknis } \\
\text { (Techical Supervision) }\end{array}$ & E.17 & 0.807 & 0.300 & Valid \\
\hline & & E.18 & 0.489 & 0.300 & Valid \\
\hline & \multirow{2}{*}{$\begin{array}{l}\text { Hubungan } \\
\text { Interpersonal antar } \\
\text { Teman Sejawat, dengan } \\
\text { Atasan dan } \\
\text { dengan Bawahan } \\
\text { (Interpersonal Relations) }\end{array}$} & E.19 & 0.711 & 0.300 & Valid \\
\hline & & E.20 & 0.613 & 0.300 & Valid \\
\hline
\end{tabular}

Sumber: Hasil Penelitian (2020) 
Berdasarkan Tabel 1 diatas maka diketahui bahwa hasil uji validitas instrumen penelitian masing-masing variabel yang digunakan untuk mengidentifikasi faktorfaktor yang memotivasi ekspatriat untuk bekerja pada hotel berbintang di Kecamatan Kuta Selatan Kabupaten Badung Bali (r hitung) lebih besar dari angka kritis tabel korelasi ( $\mathrm{r}$ tabel) 0,300 dan instrumen penelitian berkorelasi signifikan terhadap skor total. Berdasarkan hasil tersebut tidak ada variabel yang dikeluarkan karena seluruh variabel yang digunakan tersebut valid sehingga layak untuk digunakan pada tahap analisis selanjutnya. Hal ini menunjukkan bahwa instrumen yang digunakan sudah tepat untuk mengukur data terkait faktor-faktor yang memotivasi ekspatriat untuk bekerja pada hotel berbintang di Kecamatan Kuta Selatan Kabupaten Badung Bali.

\section{Uji Reliabilitas}

Hasil uji reliabilitas instrumen penelitian terhadap penelitian faktor-faktor yang memotivasi ekspatriat untuk bekerja pada hotel berbintang di Kecamatan Kuta Selatan Kabupaten Badung Bali tersaji pada Tabel 2 sebagai berikut.

Tabel 2. Hasil Uji Reliabilitas

Motivasi Intrinsik

Case Processing Summary

\begin{tabular}{ll|c|c} 
& & $\mathrm{N}$ & $\%$ \\
\hline Cases & Valid & 30 & 100.0 \\
\cline { 2 - 4 } & Excluded $^{\mathrm{a}}$ & 0 & .0 \\
\hline & Total & 30 & 100.0
\end{tabular}

a. Listwise deletion based on all variables in the procedure.

Reliability Statistics

Cronbach's Alpha $\mathrm{N}$ of Items

\begin{tabular}{l|l}
\hline $820 \quad 7$ \\
\hline
\end{tabular}


Motivasi Ekstrinsik

Case Processing Summary

\begin{tabular}{llc|c} 
& & $\mathrm{N}$ & $\%$ \\
\hline Cases & Valid & 30 & 100.0 \\
\cline { 2 - 4 } & $\begin{array}{l}\text { Excluded }^{\mathrm{a}} \\
\end{array}$ & 0 & .0 \\
\hline Total & 30 & 100.0 \\
\hline
\end{tabular}

a. Listwise deletion based on all variables in the procedure.

Reliability Statistics

Cronbach's Alpha $\mathrm{N}$ of Items

\begin{tabular}{l|l}
\hline .883 & 13 \\
\hline
\end{tabular}

Sumber: Hasil Penelitian (2020)

Berdasarkan hasil uji reliabilitas pada Tabel 2 hasil uji reliabilitas terbagi menjadi masing masing 2 tabel, tabel pertama adalah tabel Case Prossesing Summary yang menunjukkan bahwa total nilai $\mathrm{N}=30$ dan derajat persen $(\%)=100$, hal ini berarti semua jawaban sampel ikut serta dalam pengujian tanpa ada pengecualian. Tabel berikutnya adalah tabel Reliability Statictics yang menunjukkan nilai Cronbach's Alpha. Adapun pada Motivasi Intrinsik, nilai Cronbach's Alpha sebesar 0,820 Nilai $N$ of Items 7 dan pada Motivasi Ekstrinsik, nilai Cronbach's Alpha sebesar 0,883 dengan Nilai $N$ of Items 13, berdasarkan hasil tersebut diketahui bahwa nilai hasil uji reliabilitas masingmasing motivasi baik intrinsik maupun ekstrinsik adalah 0,820 dan 0,928 dimana variabel berjumlah 20 disertakan dalam uji.

Analisis Pembentukan Faktor-Faktor yang Memotivasi Ekspatriat Untuk Bekerja Pada Hotel Berbintang Di Kecamatan Kuta Selatan Kabupaten Badung Bali Adapun hasil analisis faktor yang diperoleh dapat dijelaskan sebagai berikut: 
1) Merumuskan Masalah

Faktor-faktor yang memotivasi Tenaga Kerja Asing (TKA) untuk bekerja pada hotel berbintang di Kecamatan Kuta Selatan, Kabupaten Badung, Bali yang diidentifikasi dari 20 variabel.

2) Membentuk Matriks Korelasi

Semua data variabel yang diolah dengan analisis faktor telah menghasilkan matrik korelasi. Hasil matrik korelasi digunakan untuk mengidentifikasi variabelvariabel yang saling berhubungan. Variabel-variabel yang tidak saling berhubungan dengan variabel lain dikeluarkan dari analisis. Hasil uji yang diperoleh tersaji pada Tabel 3 sebagai berikut:

Tabel 3. Nilai KMO dan Bartlett's Test

\begin{tabular}{|c|c|c|}
\hline \multicolumn{2}{|c|}{$\begin{array}{l}\text { Kaiser-Meyer-Olkin Measure of } \\
\text { Sampling Adequacy. }\end{array}$} & $\underline{0.813}$ \\
\hline \multirow[t]{3}{*}{$\begin{array}{l}\text { Bartlett's Test of } \\
\text { Sphericity }\end{array}$} & $\begin{array}{l}\text { Approx. Chi- } \\
\text { Square }\end{array}$ & 1859.421 \\
\hline & Df & 190 \\
\hline & Sig. & 0.000 \\
\hline
\end{tabular}

Sumber: Hasil Penelitian (2020)

\section{a.Uji KMO (Kaiser-Meyer-Olkin)}

Nilai KMO yang diperoleh adalah 0,813. Hasil ini menunjukkan bahwa pengambilan sampel baik memadai dengan menggunakan analisis faktor dalam matrik korelasi karena $\mathrm{KMO}$ di atas 0,5. 
b. Uji Bartlett's (Bartlett Test of Sphericity)

Nilai Bartlett Test of Sphericity yang diperoleh adalah 1859,421 dengan signifikansi 0,000. Hasil ini menunjukkan bahwa antar variabel terjadi korelasi sehingga model faktor dapat digunakan.

\section{c. Uji Measure of Sampling Adequacy (MSA)}

Uji MSA dilakukan untuk mengukur derajat korelasi antar variabel, dimana setiap variabel dianalisis untuk mengetahui variabel yang dapat diproses lebih lanjut dan variabel yang harus dikeluarkan. Variabel yang dapat diproses lebih lanjut adalah variabel dengan MSA > 0,5. Hal ini dapat dilihat pada angka korelasi yang bertanda "a" (arah diagonal dari kiri atas ke kanan bawah) pada Anti-images Matrices. Nilai MSA setiap variabel tersaji pada Tabel 4 berikut ini:

\section{Tabel 4. Anti-image Matrices}

\begin{tabular}{|c|c|c|c|c|c|c|c|c|c|c|c|c|c|c|c|c|c|c|c|c|}
\hline \multicolumn{21}{|c|}{ Anti-image Matrices } \\
\hline & I.1 & I. 2 & I. 3 & I. 4 & I.5 & I.6 & I.7 & E. 8 & E.9 & E.10 & E.11 & E.12 & E.13 & E.14 & E.15 & E.16 & E.17 & E.18 & E.19 & E.20 \\
\hline \multirow{4}{*}{$\begin{array}{l}\text { Anti- I.1 } \\
\text { image } \\
\text { Covar I.2 } \\
\text { iance }\end{array}$} & 0,261 & & $-0,045$ & & 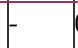 & 0,025 & 0,052 & & 0,039 & & $0,046-$ & & 0,013 & & 0,001 & 0,012 & & & & 0,034 \\
\hline & & 0,033 & & 0,063 & 0,025 & & & 0,079 & & 0,016 & & 0,006 & & 0,064 & & & 0,025 & 0,045 & 5,079 & \\
\hline & - & 0,143 & $-0,014$ & 0,003 & & & 0,007 & 0,011 & & 0,009 & & 0,057 & & 0,003 & & & 0,043 & 0,042 & 20,046 & $-0,122$ \\
\hline & 0,033 & & & & 0,003 & 0,044 & & & 0,048 & & 0,009 & & 0,015 & & 0,049 & 0,021 & & & & \\
\hline \multirow[t]{2}{*}{ I. 3} & - & & 0,250 & & 0,015 & 0,007 & & 0,031 & & & & 0,006 & 0,001 & 0,046 & & & 0,023 & 0,016 & 5,012 & $-0,006$ \\
\hline & 0,045 & 0,014 & & 0,079 & & & 0,072 & & 0,005 & 0,008 & 0,030 & & & & 0,025 & 0,130 & & & & \\
\hline \multirow[t]{2}{*}{ I. 4} & - & 0,003 & $-0,079$ & 0,310 & & & & & 0,000 & 0,010 & 0,000 & & & & 0,027 & 0,008 & & 0,045 & 5,079 & $-0,007$ \\
\hline & 0,063 & & & & 0,004 & 0,064 & 0,033 & 0,009 & & & & 0,029 & 0,008 & 0,116 & & & 0,040 & & & \\
\hline \multirow[t]{2}{*}{ I. 5} & & & 0,015 & & 0,223 & & & & 0,074 & 0,017 & & & & & & & & 0,054 & 0,038 & 0,004 \\
\hline & 0,025 & 0,003 & & 0,004 & & 0,062 & 0,017 & 0,003 & & & 0,0060 & 0,053 & 0,023 & 0,053 & 0,066 & 0,033 & 30,095 & & & \\
\hline \multirow[t]{2}{*}{ I. 6} & 0,025 & & 0,007 & & & 0,190 & 0,048 & & 0,014 & & 0,039 & & 0,025 & 0,016 & 0,050 & & & & & 0,051 \\
\hline & & 0,044 & & 0,064 & 0,062 & & & 0,031 & & 0,021 & & 0,031 & & & & 0,012 & 20,007 & 0,148 & 30,049 & \\
\hline \multirow[t]{2}{*}{ I.7 } & 0,052 & 0,007 & $-0,072$ & & & 1 & 0,422 & & 0,009 & & 0,024 & & 0,002 & & 0,031 & 0,018 & & & & $-0,043$ \\
\hline & & & & 0,033 & 30,017 & & & 0,037 & & 0,006 & & 0,003 & & 0,056 & & & 0,017 & 0,051 & 0,084 & \\
\hline \multirow[t]{2}{*}{ E. 8} & - & 0,011 & 0,031 & 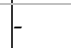 & & & - & 0,106 & & 0,030 & & 0,021 & & 0,039 & 0,012 & 0,010 & 00,019 & 0,037 & 70,006 & $-0,018$ \\
\hline & 0,079 & & & 0,009 & 0,003 & 0,031 & 0,037 & & 0,028 & & 0,085 & & 0,030 & & & & & & & \\
\hline \multirow[t]{2}{*}{ E.9 } & 0,039 & & $-0,005$ & 0,000 & 0,074 & 0,014 & 0,009 & & 0,148 & 0,012 & 0,010 & & & & & 0,016 & & & & 0,039 \\
\hline & & 0,048 & & & & & & 0,028 & & & & 0,125 & 0,015 & 0,048 & 30,042 & & 0,027 & 0,021 & $\mid 0,058$ & \\
\hline \multirow[t]{2}{*}{ E.10 } & & 0,009 & $-0,008$ & 0,010 & 0,017 & & & 0,030 & 0,012 & 20,046 & & & & 0,010 & & & 0,012 & 0,029 & & $-0,010$ \\
\hline & 0,016 & & & & & 0,021 & 0,006 & & & & 0,0350 & 50,019 & 0,045 & & 0,013 & 0,011 & & & 0,015 & \\
\hline \multirow[t]{2}{*}{ E.11 } & 0,046 & & $-0,030$ & 0,0 & & 0,039 & 0,024 & & 0, & & $0,096-$ & & 0,030 & & 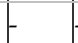 & & - & & 0,003 & 0,018 \\
\hline & & 0,009 & & & 0,006 & & & 0,085 & & 0,035 & & 0,011 & & 0,032 & 20,001 & 0,018 & 80,017 & 0,038 & & \\
\hline \multirow[t]{2}{*}{ E.12 } & 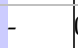 & 0,057 & 0,006 & & & & & 0,021 & & & & 0,198 & 0,010 & & 0,032 & & 0,020 & 0,025 & 50,074 & $-0,056$ \\
\hline & 0,006 & & & 0,029 & 0,053 & 0,031 & 0,003 & & 0,125 & 0,019 & 0,011 & & & 0,016 & & 0,021 & & & & \\
\hline \multirow[t]{2}{*}{ E.13 } & 0,013 & & 0,001 & & & 0,025 & 0,002 & & & & 0,0300 & 0,010 & 0,052 & & 0,009 & 0,022 & & & 0,000 & 0,016 \\
\hline & & 0,015 & & 0,008 & 30,023 & & & 0,030 & 0,015 & 50,045 & & & & 0,006 & & & 0,004 & 0,031 & & \\
\hline \multirow[t]{2}{*}{ E.14 } & - & 0,003 & 0,046 & - & & 0,016 & & 0,039 & & 0,010 & & +1 & & 0,428 & 0,010 & 0,001 & 10,035 & & & 0,005 \\
\hline & 0,064 & & & 0,116 & $(0,053$ & & 0,056 & & 0,048 & & 0,0320 & 0,016 & 0,006 & & & & & \multicolumn{2}{|c|}{$0,0140,039$} & \\
\hline
\end{tabular}




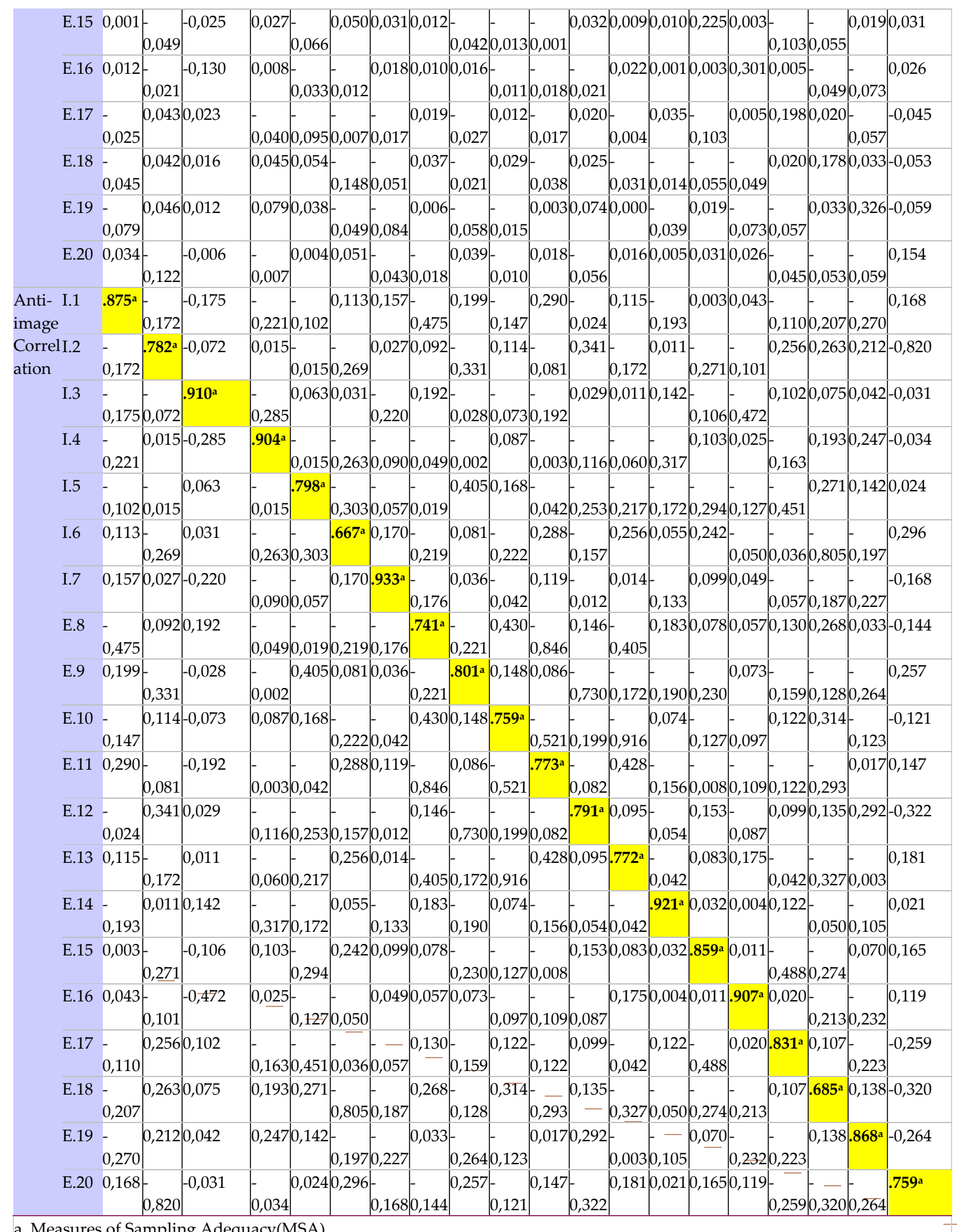

\section{Sumber: Hasil Penelitian (2020)}


Tabel 5. Nilai MSA setiap Variabel pada Anti-image Matrices

\begin{tabular}{|c|c|c|c|c|}
\hline \multicolumn{2}{|l|}{ Indikator } & MSA & Syarat MSA & Keterangan \\
\hline \multirow[t]{20}{*}{ Anti-image Correlation } & I.1 & $\underline{0.875}$ & 0.500 & Dapat Diprediksi \\
\hline & I.2 & $\underline{0.782}$ & 0.500 & Dapat Diprediksi \\
\hline & I.3 & $\underline{0.910}$ & 0.500 & Dapat Diprediksi \\
\hline & I. 4 & $\underline{0.904}$ & 0.500 & Dapat Diprediksi \\
\hline & I.5 & $\underline{0.798}$ & 0.500 & Dapat Diprediksi \\
\hline & I.6 & $\underline{0.667}$ & 0.500 & Dapat Diprediksi \\
\hline & I.7 & $\underline{0.933}$ & 0.500 & Dapat Diprediksi \\
\hline & E. 8 & $\underline{0.741}$ & 0.500 & Dapat Diprediksi \\
\hline & E. 9 & $\underline{0.801}$ & 0.500 & Dapat Diprediksi \\
\hline & E.10 & $\underline{0.759}$ & 0.500 & Dapat Diprediksi \\
\hline & E.11 & $\underline{0.773}$ & 0.500 & Dapat Diprediksi \\
\hline & E.12 & $\underline{0.791}$ & 0.500 & Dapat Diprediksi \\
\hline & E.13 & $\underline{0.772}$ & 0.500 & Dapat Diprediksi \\
\hline & E.14 & $\underline{0.921}$ & 0.500 & Dapat Diprediksi \\
\hline & E.15 & $\underline{0.859}$ & 0.500 & Dapat Diprediksi \\
\hline & E.16 & $\underline{0.907}$ & 0.500 & Dapat Diprediksi \\
\hline & E.17 & $\underline{0.831}$ & 0.500 & Dapat Diprediksi \\
\hline & E.18 & $\underline{0.685}$ & 0.500 & Dapat Diprediksi \\
\hline & E.19 & $\underline{0.868}$ & 0.500 & Dapat Diprediksi \\
\hline & E. 20 & $\underline{0.759}$ & 0.500 & Dapat Diprediksi \\
\hline
\end{tabular}

a. Measures of Sampling Adequacy (MSA)

Sumber: Hasil Penelitian (2020) 
Berdasarkan hasil Uji MSA yang tersaji pada Tabel 5, diperoleh hasil bahwa 20 variabel yang di uji telah memenuhi kriteria, karena nilai MSA masing-masing variabel $>0,5$ sehingga seluruh variabel dapat diproses ke tahap selanjutnya yaitu tahap menentukan jumlah faktor.

\section{3) Menentukan Jumlah Faktor}

Pada analisis ini perlu diperhatikan nilai communalities dan total variance explained. Nilai communalities tersaji pada Tabel 6 sebagai berikut:

\section{Tabel 6. Communalities}

\begin{tabular}{ll|l} 
& Initial & Extraction \\
\hline I.1 & 1,000 & 0,673 \\
I.2 & 1,000 & 0,786 \\
I.3 & 1,000 & 0,625 \\
I.4 & 1,000 & 0,683 \\
I.5 & 1,000 & 0,846 \\
I.6 & 1,000 & 0,867 \\
I.7 & 1,000 & 0,569 \\
E.8 & 1,000 & 0,693 \\
E.9 & 1,000 & 0,690 \\
E.10 & 1,000 & 0,803 \\
E.11 & 1,000 & 0,760 \\
E.12 & 1,000 & 0,618 \\
E.13 & 1,000 & 0,794 \\
E.14 & 1,000 & 0,567 \\
E.15 & 1,000 & 0,749 \\
E.16 & 1,000 & 0,626 \\
E.17 & 1,000 & 0,854 \\
E.18 & 1,000 & 0,836 \\
E.19 & 1,000 & 0,586 \\
E.20 & 1,000 & 0,807 \\
\hline
\end{tabular}

Extraction Method: Principal Component Analysis.

Sumber: Hasil Penelitian (2020) 
Nilai communalities masing-masing variabel menunjukkan seberapa besar sebuah variabel dapat menjelaskan faktor, angka pada kolom extraction. Semakin besar communality sebuah variabel berarti semakin erat hubungannya dengan faktor yang terbentuk. Pada Tabel 6 konstribusi variabel hasil ekstraksi menunjukkan besarnya variansi variabel yang disaring dengan variabel lainnya.

Setelah diketahui nilai communalities, bentukan banyaknya jumlah faktor dapat diputuskan berdasarkan pada besarnya eigenvalue setiap faktor yang muncul. Semakin besar eigenvalue setiap faktor, semakin representatif faktor tersebut untuk mewakili sekelompok variabel. Faktor-faktor inti yang dipilih adalah faktor yang mempunyai eigenvalue $\geq 1$, sehingga dapat diartikan bahwa faktor tersebut dapat menjelaskan variabel yang terwakili dengan baik. Hasil penentuan jumlah faktor tersaji secara rinci pada Tabel 7 berikut.

Tabel 7. Total Variance Explained

\begin{tabular}{|c|c|c|c|c|c|c|}
\hline \multicolumn{4}{|c|}{ Initial Eigenvalues } & \multicolumn{3}{|c|}{ Extraction Sums of Squared Loadings } \\
\hline Component & Total & $\begin{array}{l}\% \text { of } \\
\text { Variance }\end{array}$ & $\begin{array}{c}\text { Cumulative } \\
\%\end{array}$ & Total & $\mid \begin{array}{c}\% \text { of } \\
\text { Variance }\end{array}$ & Cumulative \% \\
\hline 1 & 9,890 & 49,449 & 49,449 & 9,890 & 49,449 & 49,449 \\
\hline 2 & 1,906 & 9,529 & 58,978 & 1,906 & 9,529 & 58,978 \\
\hline 3 & 1,364 & 6,821 & 65,799 & 1,364 & 6,821 & 65,799 \\
\hline 4 & 1,272 & 6,362 & 72,161 & 1,272 & 6,362 & 72,161 \\
\hline 5 & 0,961 & 4,805 & 76,966 & & & \\
\hline 6 & 0,824 & 4,119 & 81,085 & & & \\
\hline 7 & 0,687 & 3,436 & 84,521 & & & \\
\hline 8 & 0,610 & 3,049 & 87,570 & & & \\
\hline 9 & 0,465 & 2,324 & 89,893 & & & \\
\hline 10 & 0,429 & 2,144 & 92,037 & & & \\
\hline
\end{tabular}




\begin{tabular}{llll|l|l|l|}
11 & 0,355 & 1,775 & 93,812 & & & \\
12 & 0,306 & 1,529 & 95,341 & & & \\
13 & 0,226 & 1,131 & 96,472 & & & \\
14 & 0,173 & 0,867 & 97,338 & & & \\
15 & 0,160 & 0,801 & 98,140 & & & \\
16 & 0,122 & 0,611 & 98,751 & & & \\
17 & 0,103 & 0,516 & 99,267 & & & \\
18 & 0,073 & 0,367 & 99,634 & & & \\
19 & 0,052 & 0,262 & 99,895 & & & \\
20 & 0,021 & 0,105 & 100,000 & & & \\
\hline
\end{tabular}

Extraction Method: Principal Component Analysis.

Sumber: Hasil Penelitian (2020)

Berdasarkan Tabel 7 diatas, dapat dilihat bahwa dalam tahap ini terbentuk sebanyak 4 (empat) faktor yang mempengaruhi ekspatriat untuk bekerja pada hotel berbintang di Kecamatan Kuta Selatan Kabupaten Badung Bali. Keempat faktor tersebut mampu menjelaskan keragaman dari variabel yang ada dalam data sebesar $72,1 \%$.

4) Rotasi Faktor

Setelah diketahui bahwa faktor yang terbentuk sebanyak 4 (empat) maka setelah rotasi menunjukan distribusi 20 variabel terhadap 4 faktor yang terbentuk. Dalam penelitian ini digunakan rotasi varimax, rotasi varimax dipilih karena hasil pengelompokkan mudah dianalisis secara teori. Hasil rotasi varimax tersebut tersaji pada Tabel 8 berikut: 
Tabel 8. Rotated Component Matrix

Component

\begin{tabular}{|c|c|c|c|c|}
\hline & 1 & 2 & 3 & 4 \\
\hline I.1 & 0,497 & 0,185 & 0,542 & 0,314 \\
\hline I. 2 & 0,283 & 0,790 & 0,216 & 0,190 \\
\hline I. 3 & 0,521 & 0,433 & 0,238 & 0,332 \\
\hline I. 4 & 0,517 & 0,005 & 0,512 & 0,391 \\
\hline I.5 & 0,156 & 0,089 & 0,884 & 0,180 \\
\hline I. 6 & 0,094 & 0,087 & 0,207 & 0,898 \\
\hline I.7 & 0,431 & 0,557 & 0,182 & 0,201 \\
\hline E. 8 & 0,768 & 0,141 & 0,276 & 0,085 \\
\hline E.9 & 0,706 & 0,386 & 0,037 & 0,204 \\
\hline E.10 & 0,812 & 0,373 & 0,067 & 0,027 \\
\hline E.11 & 0,807 & 0,196 & 0,242 & 0,109 \\
\hline E.12 & 0,729 & 0,144 & 0,073 & 0,247 \\
\hline E.13 & 0,800 & 0,376 & 0,107 & 0,017 \\
\hline E.14 & 0,558 & 0,051 & 0,367 & 0,343 \\
\hline E.15 & 0,181 & 0,501 & 0,675 & 0,101 \\
\hline E.16 & 0,310 & 0,335 & 0,239 & 0,601 \\
\hline E.17 & 0,111 & 0,347 & 0,842 & 0,107 \\
\hline E.18 & 0,142 & 0,328 & 0,081 & 0,837 \\
\hline E.19 & 0,381 & 0,578 & 0,198 & 0,260 \\
\hline E.20 & 0,211 & 0,833 & 0,200 & 0,171 \\
\hline
\end{tabular}

Extraction Method: Principal Component Analysis.

Rotation Method: Varimax with Kaiser Normalization.

a.Rotation converged in 6 iterations.

Sumber: Hasil Penelitian (2020) 
Berdasarkan hasil analisis rotasi pada Tabel 8 maka dapat dijelaskan bahwa dari 20 variabel yang dirotasi, seluruh variabel memenuhi syarat karena telah melewati factor loading $>0,5$. Hasil rotasi menunjukkan bahwa semua variabel memilki kelompok faktor, variabel yang sebelumnya belum jelas berada pada faktor berapa, setelah melakukan rotasi variabel berada pada kelompok faktor yang memiliki nilai loading terbesar. Faktor dapat dikelompokkan sesuai dengan variabel pembentuknya yang tersaji pada Tabel 9 sebagai berikut:

Tabel 9. Kelompok Faktor Hasil Rotasi

\begin{tabular}{|c|c|c|c|}
\hline Faktor & Item & Loading Faktor & $\%$ Varian \\
\hline \multirow{9}{*}{ Faktor 1} & I.3 & 0,521 & \multirow{9}{*}{49,449} \\
\hline & I. 4 & 0,517 & \\
\hline & E. 8 & 0,768 & \\
\hline & E.9 & 0,706 & \\
\hline & E.10 & 0,812 & \\
\hline & E.11 & 0,807 & \\
\hline & E.12 & 0,729 & \\
\hline & E.13 & 0,800 & \\
\hline & E.14 & 0,558 & \\
\hline \multirow{4}{*}{ Faktor 2} & I. 2 & 0,790 & \multirow{4}{*}{9,529} \\
\hline & I.7 & 0,557 & \\
\hline & E.19 & 0,578 & \\
\hline & E.20 & 0,833 & \\
\hline \multirow{4}{*}{ Faktor 3} & I.1 & 0,542 & \multirow{4}{*}{6,821} \\
\hline & I.5 & 0,884 & \\
\hline & E.15 & 0,675 & \\
\hline & E.17 & 0,842 & \\
\hline \multirow[b]{3}{*}{ Faktor 4} & I.6 & 0,898 & \multirow[b]{3}{*}{6,362} \\
\hline & E.16 & 0,601 & \\
\hline & E.18 & 0,837 & \\
\hline \multicolumn{4}{|c|}{$\begin{array}{l}\text { Extraction Method: Principal Component Analysis. } \\
\text { Rotation Method: Varimax with Kaiser Normalization. }\end{array}$} \\
\hline \multicolumn{4}{|c|}{ a. Rotation converged in 6 iterations. } \\
\hline
\end{tabular}

Sumber: Hasil Penelitian (2020) 
Berdasarkan Tabel 9 diketahui bahwa Faktor 1 terdiri dari 9 (sembilan) variabel yang berkorelasi yaitu Tanggung Jawab (Responsibility) (I.3), Kemajuan (Advancement) (I.4), Kompensasi (Payment and Status) (E.8), Kompensasi (Payment and Status) (E.9), Kompensasi (Payment and Status) (E.10), Keamanan dan Keselamatan Kerja (Job Security) (E.11), Keamanan dan Keselamatan Kerja (Job Security) (E.12), Kondisi Kerja (Working Conditions) (E.13), dan Kondisi Kerja (Working Conditions) (E.14). Faktor 2 terdiri dari 4 (empat) variabel yang berkorelasi yaitu Pengakuan (Recognition) (I.2), Perkembangan (Personal Development) (I.7), Hubungan Interpersonal dengan Atasan (Interpersonal Relation) (E.19), dan Hubungan Interpersonal dengan Bawahan (Interpersonal Relation) (E.20). Faktor 3 terdiri dari 4 (empat) variabel yang berkorelasi yaitu Prestasi (Achievement) (I.1), Pekerjaan Itu Sendiri (Work Itself) (I.5), Kebijakan (Company Policy and Administration) (E.15), dan Supervisi Teknis (Technical Supervision) (E.17). Faktor 4 terdiri dari 3 (tiga) variabel yang berkorelasi yaitu Perkembangan (Personal Growth) (I.6), Kebijakan (Company Policy and Administration) (E.16) dan Hubungan Interpersonal Antar Teman Sejawat (Interpersonal Relation) (E.18).

5) Interpretasi Faktor

Pada penelitian ini seluruh variabel yaitu sebanyak 20 variabel memenuhi factor loading $>0,5$ yang tersebar ke dalam 4 (empat) faktor. Adapun pemberian nama terhadap faktor yang terbentuk dilakukan pada tahap ini dengan mengacu pada variabel-variabel pembentuk faktor tersebut atau berdasarkan variabel dengan factor loading tertinggi. Hasil dari interpretasi faktor tersaji pada Tabel 10 berikut. 
Tabel 10. Faktor-Faktor yang Memotivasi Ekspatriat untuk Bekerja pada Hotel Berbintang di Kecamatan Kuta Selatan Kabupaten Badung Bali

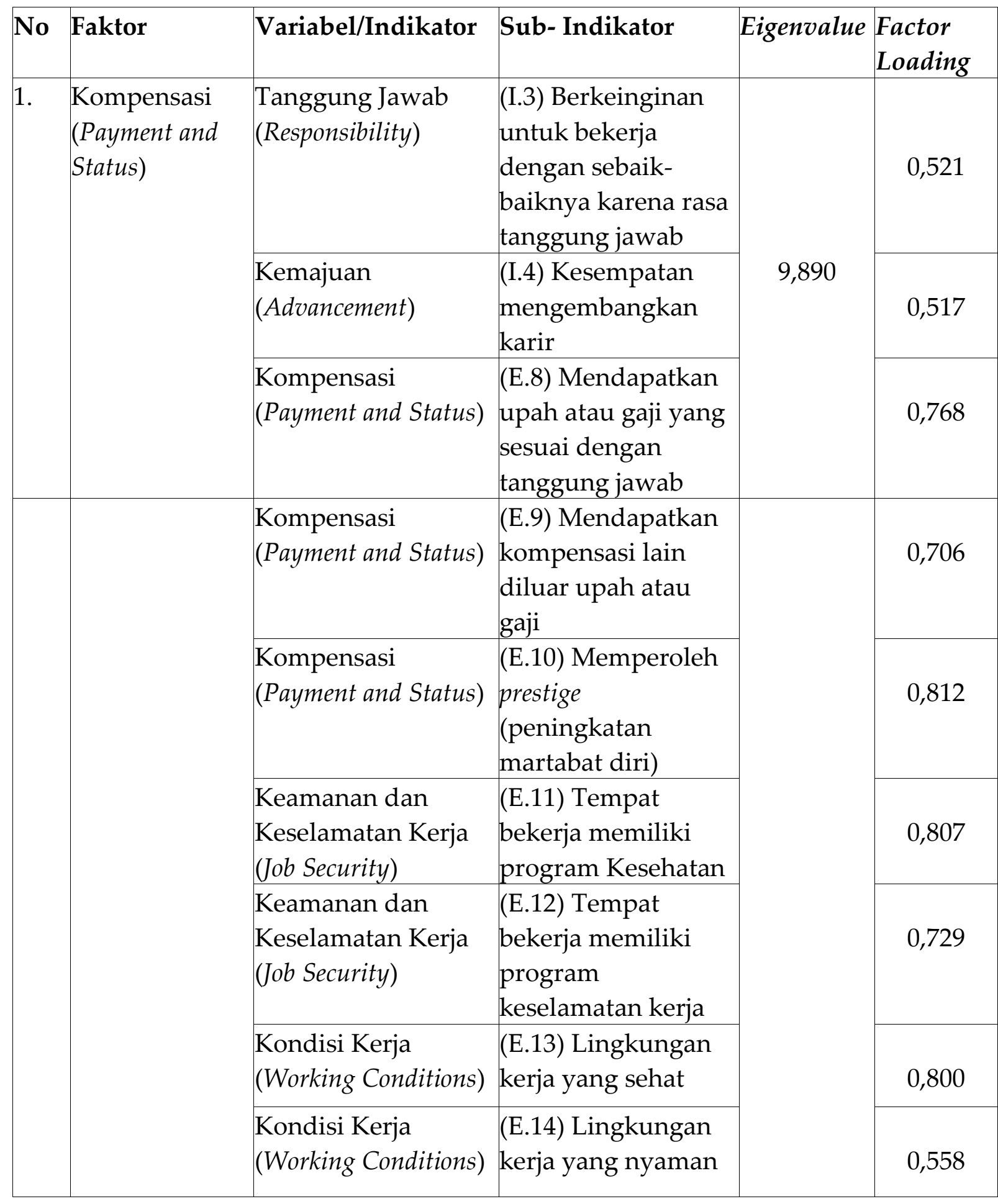




\begin{tabular}{|c|c|c|c|c|c|}
\hline \multirow[t]{4}{*}{2.} & $\begin{array}{l}\text { Hubungan } \\
\text { Interpersonal } \\
\text { dengan } \\
\text { Bawahan } \\
\text { (Interpersonal } \\
\text { Relation) }\end{array}$ & $\begin{array}{l}\text { Pengakuan } \\
\text { (Recognition) }\end{array}$ & $\begin{array}{l}\text { (I.2) Bekerja guna } \\
\text { mendapatkan } \\
\text { penilaian yang baik } \\
\text { dari perusahaan } \\
\text { terhadap kinerja } \\
\text { yang sudah } \\
\text { dilakukan }\end{array}$ & \multirow{4}{*}{1,906} & 0,790 \\
\hline & & $\begin{array}{l}\text { Perkembangan } \\
\text { (Personal Growth) }\end{array}$ & $\begin{array}{l}\text { (I.7) Mendapatkan } \\
\text { program pelatihan } \\
\text { di luar tempat kerja }\end{array}$ & & 0,557 \\
\hline & & $\begin{array}{l}\text { Hubungan } \\
\text { Interpersonal } \\
\text { dengan Atasan } \\
\text { (Interpersonal } \\
\text { Relation) } \\
\end{array}$ & $\begin{array}{l}\text { (E.19) Mampu } \\
\text { beradaptasi dengan } \\
\text { atasan }\end{array}$ & & 0,578 \\
\hline & & $\begin{array}{l}\text { Hubungan } \\
\text { Interpersonal } \\
\text { dengan Bawahan } \\
\text { (Interpersonal } \\
\text { Relation) }\end{array}$ & $\begin{array}{l}\text { (E.20) Mampu } \\
\text { beradaptasi dengan } \\
\text { bawahan }\end{array}$ & & 0,833 \\
\hline \multirow[t]{4}{*}{3.} & \multirow[t]{2}{*}{$\begin{array}{l}\text { Pekerjaan itu } \\
\text { sendiri (Work } \\
\text { Itself) }\end{array}$} & $\begin{array}{l}\text { Prestasi } \\
\text { (Achievement) }\end{array}$ & $\begin{array}{l}\text { (I.1) Bekerja guna } \\
\text { meningkatkan } \\
\text { prestasi diri dalam } \\
\text { perusahaan }\end{array}$ & \multirow[t]{2}{*}{1,364} & 0,542 \\
\hline & & $\begin{array}{l}\text { Pekerjaan itu sendiri } \\
\text { (Work Itself) }\end{array}$ & $\begin{array}{l}\text { (I.5) Menyukai tugas } \\
\text { pekerjaan yang } \\
\text { diberikan } \\
\text { perusahaan }\end{array}$ & & 0,884 \\
\hline & & $\begin{array}{l}\text { Kebijakan (Company } \\
\text { Policy) }\end{array}$ & $\begin{array}{l}\text { (E.15) Ketersediaan } \\
\text { informasi yang } \\
\text { memadai mengenai } \\
\text { aturan perusahaan }\end{array}$ & & 0,675 \\
\hline & & $\begin{array}{l}\text { Supervisi Teknis } \\
\text { (Technical } \\
\text { Supervision) }\end{array}$ & $\begin{array}{l}\text { (E.17) Perusahaan } \\
\text { memiliki Supervisi } \\
\text { Teknis yang baik }\end{array}$ & & 0,842 \\
\hline
\end{tabular}




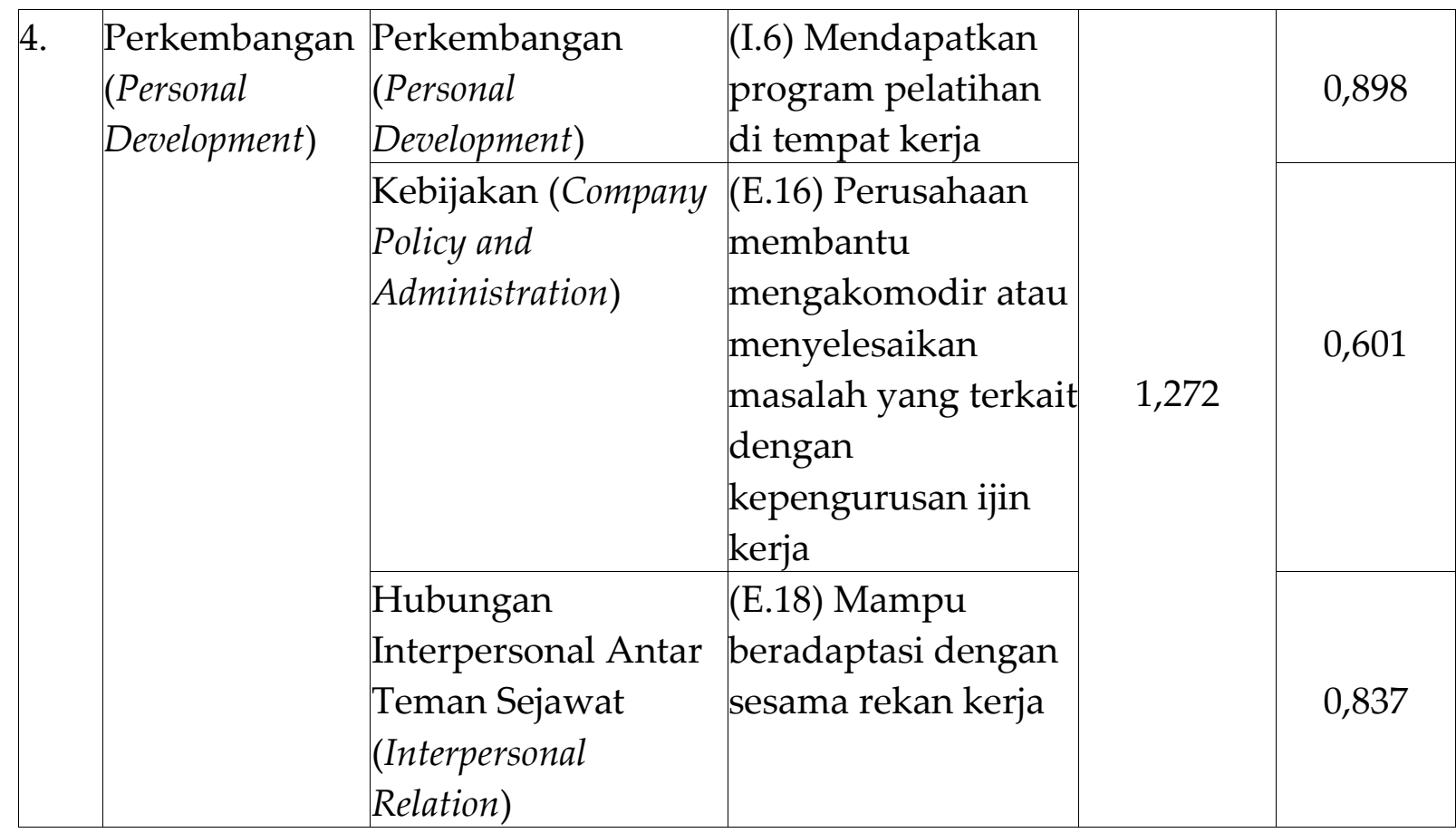

Sumber: Hasil Penelitian (2020)

Pada Tabel 10 diketahui bahwa 20 variabel yang mempunyai factor loading $>0,5$ tersebar ke dalam 4 (empat) faktor.

Berdasarkan hasil analisis faktor diketahui dari dua puluh variabel yang diteliti tereduksi menjadi 4 (empat) faktor. Adapun uraian 4 (empat) faktor tersebut antara lain faktor pertama yakni, Faktor Kompesasi (Payment and Status). Faktor Kompesasi (Payment and Status) merupakan faktor yang memotivasi Ekspatriat untuk Bekerja pada Hotel Berbintang di Kecamatan Kuta Selatan Kabupaten Badung Bali dengan eigenvalue sebesar 9,890. Faktor ini terdiri dari 9 (sembilan) variabel yaitu Tanggung Jawab (Responsibility), sub-indikator (I.3) Berkeinginan untuk bekerja dengan sebaikbaiknya karena rasa tanggung jawab dengan factor loading sebesar 0,521 kemudian Kemajuan (Advancement), sub-indikator (I.4) Kesempatan mengembangkan karir sebesar 0.517, Kompensasi (Payment and Status), sub-indikator (E.8) Mendapatkan upah atau gaji yang sesuai dengan tanggung jawab sebesar 0,768, Kompensasi (Payment and Status), sub- indikator (E.9) Mendapatkan kompensasi lain diluar upah atau gaji sebesar 0,706, Kompensasi (Payment and Status), sub-indikator (E.10) 
Memperoleh prestige (peningkatan martabat diri) sebesar 0,812, Keamanan dan Keselamatan Kerja (Job Security), sub-indikator (E.11) Tempat bekerja memiliki program Kesehatan sebesar 0,807, Keamanan dan Keselamatan Kerja (Job Security), sub-indikator (E.12) Tempat bekerja memiliki program keselamatan kerja sebesar 0,729, Kondisi Kerja (Working Condition), sub-indikator (E.13) Lingkungan kerja yang sehat sebesar 0,800, dan Kondisi Kerja (Working Condition), sub-indikator (E.14) Lingkungan kerja yang nyaman sebesar 0,558. Hal ini menunjukkan bahwa ada sekelompok ekspatriat yang bekerja pada hotel- hotel berbintang di Kecamatan Kuta Selatan, Kabupaten Badung, Bali karena dimotivasi oleh variabel-variabel yang terdapat dalam faktor Kompesasi (Payment and Status), terutama variabel Kompensasi (Payment and Status), sub-indikator E.10 yakni memperoleh prestige (peningkatan martabat diri) dilihat dari factor loading paling besar.

Faktor kedua yakni, Faktor Hubungan Interpersonal dengan Bawahan (Interpersonal Relation). Faktor Hubungan Interpersonal dengan Bawahan (Interpersonal Relation) merupakan faktor yang memotivasi Ekspatriat untuk Bekerja pada Hotel Berbintang di Kecamatan Kuta Selatan Kabupaten Badung Bali dengan eigenvalue sebesar 1,906. Faktor ini terdiri dari 4 (empat) variabel yaitu Pengakuan (Recognition), sub- indikator (I.2) Bekerja guna mendapatkan penilaian yang baik dari perusahaan terhadap kinerja yang sudah dilakukan dengan factor loading sebesar 0,790, kemudian Perkembangan (Personal Development), sub-indikator (I.7) Mendapatkan program pelatihan di luar tempat kerja sebesar 0,557, Hubungan Interpersonal dengan Atasan (Interpersonal Relation), sub-indikator (E.19) Mampu beradaptasi dengan atasan sebesar 0,578, dan Hubungan Interpersonal dengan Bawahan (Interpersonal Relation), sub- indikator (E.20) Mampu beradaptasi dengan bawahan sebesar 0,833. Hal ini menunjukkan bahwa ada sekelompok ekspatriat yang bekerja pada hotel-hotel berbintang di Kecamatan Kuta Selatan, Kabupaten Badung, Bali karena dimotivasi oleh variabel-variabel yang terdapat dalam faktor kedua, terutama variabel Hubungan Interpersonal dengan Bawahan (Interpersonal Relation), 
sub-indikator E.20 yakni mampu beradaptasi dengan bawahan dilihat dari factor loading paling besar.

Faktor ketiga yakni, Faktor Pekerjaan itu sendiri (Work Itself). Faktor Pekerjaan itu sendiri (Work Itself) merupakan faktor yang memotivasi Ekspatriat untuk Bekerja pada Hotel Berbintang di Kecamatan Kuta Selatan Kabupaten Badung Bali dengan eigenvalue sebesar 1,364. Faktor ini terdiri dari 4 (empat) variabel yaitu Prestasi (Achievement), sub- indikator (I.1) Bekerja guna meningkatkan prestasi diri dalam perusahaan dengan factor loading sebesar 0,542, kemudian Pekerjaan itu sendiri (Work Itself), sub-indikator (I.5) Menyukai tugas pekerjaan yang diberikan perusahaan sebesar 0,884, Kebijakan (Company Policy), sub-indikator (E.15) Ketersediaan informasi yang memadai mengenai aturan perusahaan sebesar 0,675 dan Supervisi Teknis (Technical Supervision), sub-indikator (E.17) Perusahaan memiliki Supervisi Teknis yang baik sebesar 0,842. Hal ini menunjukkan bahwa ada sekelompok ekspatriat yang bekerja pada hotel-hotel berbintang di Kecamatan Kuta Selatan, Kabupaten Badug, Bali karena dimotivasi oleh variabel- variabel yang terdapat dalam faktor Pekerjaan itu sendiri (Work Itself), terutama variabel Pekerjaan itu sendiri (Work Itself), subindikator (I.5) yakni menyukai tugas pekerjaan yang diberikan perusahaan dilihat dari factor loading paling besar.

Faktor keempat yakni, Faktor Perkembangan (Personal Development). Faktor Perkembangan (Personal Development) merupakan faktor yang memotivasi Ekspatriat untuk Bekerja pada Hotel Berbintang di Kecamatan Kuta Selatan Kabupaten Badung Bali dengan eigenvalue sebesar 1,272. Faktor ini terdiri dari 3 (tiga) variabel yaitu Perkembangan (Personal Development), sub-indikator (I.6) Mendapatkan program pelatihan di tempat kerja factor loading sebesar 0,898 kemudian Kebijakan (Company Policy and Administration), sub-indikator (E.16) Perusahaan membantu mengakomodir atau menyelesaikan masalah yang terkait dengan kepengurusan ijin kerja sebesar 0,601 dan Hubungan Interpersonal Antar Teman Sejawat (Interpersonal Relation), sub- 
indikator (E.18) Mampu beradaptasi dengan sesama rekan kerja sebesar 0,837. Hal ini menunjukkan bahwa ada sekelompok ekspatriat yang bekerja pada hotel-hotel berbintang di Kecamatan Kuta Selatan, Kabupaten Badug, Bali karena dimotivasi oleh variabel-variabel yang terdapat dalam faktor Perkembangan (Personal Development), terutama variabel Perkembangan (Personal Development), sub-indikator (I.6) yakni mendapatkan program pelatihan di tempat kerja dilihat dari factor loading paling besar.

\section{Simpulan dan Saran}

Berdasarkan hasil analisis faktor diketahui dari dua puluh variabel yang diteliti tereduksi menjadi 4 (empat) faktor. Adapun uraian 4 (empat) faktor tersebut antara lain faktor pertama yakni, Faktor Kompesasi (Payment and Status), Faktor Hubungan Interpersonal dengan Bawahan (Interpersonal Relation), Faktor Pekerjaan itu sendiri (Work Itself), dan Faktor Perkembangan (Personal Development).

Adapun saran secara akademis berdasarkan hasil dari penelitian ini adalah perlu diadakan penelitian lanjutan yang memperhatikan faktor lokasi dan iklim yang memotivasi ekspatriat untuk bekerja. Kemudian, secara praktis hasil penelitian ini diharapkan dapat bermanfaat bagi stakeholder pariwisata sehingga dapat menjadi bahan pertimbangan didalam pembuatan kebijakan pariwisata yang terkait dengan tenaga kerja asing. Seiring dengan peningkatan jumlah tenaga kerja asing yang bekerja di Bali, tenaga kerja lokal khususnya masyarakat Bali diharapkan untuk bersiap menerima persaingan global seiring dengan masuknya era Masyarakat Ekonomi ASEAN (MEA) yang akan mempengaruhi peningkatan jumlah tenaga kerja asing yang bekerja di Bali. 


\section{Daftar Pustaka}

Abdullah, H.M. Ma'ruf. 2015. Metodologi Penelitian Kuantitatif. Yogyakarta: CV. Aswaja Pressindo.

Bappeda Kabupaten Badung. 2017. "Profil Pariwisata", Sumber: http://www.bappeda.badungkab.go.id/assets/img/dokumen/PROFILPARIWISATA.pdf. Diakses: 14/10/2017.

BPS Kabupaten Badung. 2016. "Kecamatan Kuta Selatan Dalam Angka”, Sumber: https://badungkab.bps.go.id/web5103/website/pdf publikasi/KecamatanKuta-Selatan- Dalam-Angka-2017--.pdf. Diakses: 10/10/2018.

BPS Kabupaten Badung. 2019. "Kecamatan Kuta Selatan Dalam Angka”, Sumber: https://badungkab.bps.go.id/publication/2019/09/26/77ca3af3f67d1bcd7c387d7 7/kecamat an-kuta-selatan-dalam-angka-2019.html. Diakses: 28/09/2019.

BPS Provinsi Bali. 2019. “Jumlah Hotel Bintang di Bali Menurut Kabupaten/Kota dan Kelas, 2000-2019"

https://bali.bps.go.id/dynamictable/2017/06/05/174/banyaknya-hotelberbintang-di-bali-menurut-lokasi-dan-kelas-hotel-2000-2010.html. Diakses: 21/06/2019.

Badan Pusat Statistik. 2017. “Tingkat Penghunian Kamar pada Hotel Bintang di Indonesia, $2008 \quad$ - $\quad 2020 ", \quad$ Sumber: https://www.bps.go.id/linkTableDinamis/view/id/980. Diakses: 10/10/2017.

Badan Pusat Statistik. 2018. "Statistik Hotel dan Akomodasi Lainnya di Indonesia”, Sumber:

https://www.bps.go.id/publication/2019/04/11/d64817c1f0294f59556bc76b/stati stik- hotel-dan-akomodasi-lainnya-di-indonesia-2018.html. Diakses: $11 / 05 / 2019$.

Disperinaker. 2017. "Seribuan WN Asing Tercatat Kerja di Badung", Sumber: https://www.balipost.com/news/2018/04/26/44030/Seribuan-WN-Asing Tercatat- Kerja.html. Diakses: 21/05/2018.

Hariandja, Marihot Tua Efendi. 2002. Manajemen Sumber Daya Manusia. Jakarta: PT. Grasindo.

Hasibuan, Malayu S.P. 2006. Manajemen Dasar, Pengertian, dan. Masalah, Edisi Revisi. Jakarta: PT. Bumi Aksara.

Hasibuan, H. Malayu S.P. 2013. Manajemen Sumber Daya Manusia, Edisi Revisi. Jakarta: PT. Bumi Aksara. 
Hair, et al. (2010). Multivariate Data Analyisis Seventh Edition. Harlow: Pearson Prentice Hall.

Herzberg, F. 1966. Work and the Nature of Man. New York: World Publishing. Purnamasari, Fitriana. 2013. Analisis Teori Motivasi Dua Faktor: Herzberg's Motivation Hygiene Theory. Bogor: Institut Pertanian Bogor.

Siagian, S. P. 2006. Manajemen Sumber Daya Manusia, Cetakan Ketiga Belas. Jakarta: Bumi Aksara.

Suliyanto. 2005. Analisis Data Dalam Aplikasi Pemasaran. Bogor: Ghalia.

Smirnova, Anna. 2017. "Pengaruh Dimensi Budaya Organisasi Terhadap Turnover Intention Ekspatriat Pada Hotel Bintang Lima di Nusa Dua-Bali", E-Jurnal Ekonomi dan Bisnis Universitas Udayana Vol. 6, No. 2, pp. 417-444.

Undang-Undang Republik Indonesia Nomor 1 Tahun 1967 Tentang Penanaman Modal Asing, Sumber: http://www.dpr.go.id/dokjdih/document/uu/UU 1967 1.pdf. $\quad$ Diakses: 02/10/17.

Undang Undang (UU) No. 13 tahun 2003 tentang Ketenagakerjaan. Website Kecamatan Kuta Selatan. Searah dan Luas Wilayah. Sumber: http://badungkab.go.id/instansi/kutaselatan/. Diakses: 3/10/2017

\section{Ucapan Terimakasih}

Penulis mengucapkan terima kasih kepada Ibu Dr. Ir. I Gusti Ayu Oka Suryawardani, M.Mgt., Ph.D selaku Koordinator Program Studi Magister Pariwisata Universitas Udayana. Selain itu penulis juga berterimakasih atas arahan Bapak Ir. A.A. Putu Agung Suryawan Wiranatha, M.Sc., Ph.D selaku pembimbing I dan Bapak Dr. I Putu Gde Sukaatmadja, S.E., M.P. selaku pembimbing II. 


\section{Profil Penulis}

Putu Yunita Wacana Sari lahir di Denpasar, 8 Juni 1993. Menyelesaikan pendidikan S1 pada Program Studi Sastra Inggris Fakultas Ilmu Budaya Universitas Udayana tahun 2015. Kemudian melanjutkan studinya ke Program Magister Pariwisata Universitas Udayana tahun 2016. Saat ini bekerja di salah satu hotel berbintang di Kecamatan Kuta Selatan, Kabupaten Badung, Bali.

Agung Suryawan Wiranatha memperoleh gelar Master dibidang Environmental Management dari Griffith University, Australia dan gelar Doktor di bidang Regional Planning dari University of Queensland, Australia. Menjadi dosen di Universitas Udayana sejak tahun 1989. Saat ini sedang menjabat sebagai Kepala Pusat Penelitian Kebudayaan dan Kepariwisataan Universitas Udayana sejak tahun 2004, sebagai Sekretaris Program Studi Doktor (S3) Pariwisata Universitas Udayana sejak tahun 2010, dan sebagai Ketua Konsorsium Riset Pariwisata sejak tahun 2013. Banyak melakukan riset kebijakan dan perencanaan pembangunan kepariwisataan di Bali maupun di Indonesia.

I Putu Gde Sukaatmadja lahir di Sumba Timur, Juli 1960. Meraih gelar Sarjana Ekonomi pada tahun 1960 di Universitas Udayana. Menempuh jenjang Magister (S2) Manajemen Pertanian pada tahun 1994, dan jenjang Doktor (S3) Manajemen Pemasaran pada tahun 2001 di Universitas Padjadjaran Bandung. Saat ini aktif mengajar sebagai dosen Magister Ilmu Manajemen, Prodi Doktor Ilmu Manajemen dan Prodi Doktor Kajian Pariwisata di Universitas Udayana Bali. Selain itu, juga aktif sebagai dosen Magister Ilmu Manajemen di Universitas Trisakti, Jakarta. Karya buku yang telah dirilis adalah Manajemen Pemasaran Pariwisata (2014). Email: sukaatmadja@yahoo.co.id. 